ISSN 2657-0203

e-ISSN 2686-0244

\title{
SOSIALISASI PERAN KELUARGA SEBAGAI PONDASI PENGUATAN MOTIVASI BELAJAR SISWA DI TENGAH PANDEMI COVID-19
}

\author{
Lusiana Rahmatiani $^{1}$, Sri Wulan Anggraeni ${ }^{2}$ \\ Universitas Buana Perjuangan Karawang \\ Pendidikan Pancasila dan Kewarganegaraan ${ }^{1}$, Pendidikan Guru Sekolah Dasar ${ }^{2}$ \\ Fakultas Keguruan dan Ilmu Pendidikan, Universitas Buana Perjuangan Karawang \\ $\underline{\text { lusiana.rahmatiani@ubpkarawang.ac.id }}{ }^{1}$, wulan.anggraeni@ubpkarawang.ac.id ${ }^{2}$
}

\begin{abstract}
Abstrak
Kegiatan pengabdian masyarakat ini memiliki tujuan untuk memberikan sosialisasi peran keluarga sebagai pondasi penguatan motivasi belajar siswa di tengah pandemi Covid-19 pada masyarakat desa jatisari kabupaten karawang. Metode yang digunakan dalam mencapai tujuan pelaksanaan kegiatan pengabdian yang dilaksanakan di tengah pandemi covid-19 ini melalui ceramah dan tanya jawab dengan pertemuan melalui zoom meeting. Pelaksanaan pengabdian dilaksanakan pada bulan Agustus 2020. Hadirnya sosialisasi peran keluarga sebagai pondasi penguatan motivasi belajar siswa ditengah pandemi Covid-19 diharapkan mampu memberikan edukasi kepada masyarakat mengenai pentingnya peran keluarga sebagai pondasi penguatan motivasi belajar siswa sehingga meminimalisir penurunan motivasi siswa dalam belajar dirumah, pelaksanaan pembelajaran dapat dilakukan melalui metode dan media sosial yang mendukung termotivasinya siswa dalam belajar, juga pentingnya peran keluarga dalam memberikan pemahaman kepada anak mengenai bahaya kesehatan dari covid-19. Dengan demikian diharapkan tumbuhnya pemahaman peran keluarga dalam penguatan motivasi siswa belajar dirumah selama masa pandemi covid-19 dengan tetap menjaga kesehatan sesuai anjuran dari pemerintah untuk tetap mengedepankan protokol kesehatan dalam pembelajaran dirumah, karena sehat menjadi kunci utama dalam belajar.
\end{abstract}

\section{Kata Kunci: Peran Keluarga, Motivasi Belajar.}

\begin{abstract}
Abstrac
This community service activity aims to provide socialization on the role of the family as a foundation for strengthening student motivation in the Covid-19 pandemic in the village community of Jatisari, Karawang district. The method used in achieving the implementation of service activities carried out in the Covid-19 pandemic is through lectures and questions and answers with meetings through zoom meetings. The implementation of the service was carried out in August 2020. The socialization of the role of the family as a foundation for strengthening student motivation in the Covid-19 pandemic is expected to be able to provide education to the community about the importance of the role of the
\end{abstract}


family as a foundation for strengthening student learning motivation to minimize the decrease in student motivation in learning at home, implementing learning This can be done through methods and social media that support student motivation in learning, as well as the importance of the role of the family in providing understanding to children about the health dangers of Covid-19. Thus it is hoped that the understanding of the role of the family in the motivation of students who study at home during the Covid-19 pandemic will grow while maintaining health according to recommendations from the government to continue to prioritize health protocols in learning at home, because being healthy is the main key in learning.

Keywords: Family Role, Learning Motivation 


\section{PENDAHULUAN}

Dunia mengalami krisis kesehatan dengan datangnya tamu yang dapat menyebabkan kematian. Tamu yang dikenal luas dengan sebutan Covid-19, yakni virus yang menyerang sistem pernapasan. Dunia medis menyebutnya virus corona atau severe acute respiratory syndrome coronavirus 2 (SARS-CoV-2). Virus ini menyerang dan melumpuhkan semua elemen kehidupan, terutama pada bidang ekonomi yang sangat berdampak buruk dirasakan oleh seluruh negara. Pelemahan pada berbagai bidang kehidupan dari efek domino covid-19 tak luput ikut dirasakan oleh seluruh lapisan masyarakat Indonesia juga berdampak pada bidang pendidikan yang menyebabkan adanya pembatasan sosial atau pemberlakukan social distancing yang dianjurkan oleh pemerintah untuk adanya pembatasan sosial untuk diam di rumah, belajar di rumah, dan bekerja dari rumah. Dalam menghadapi situasi sulit seperti sekarang ini, peranan keluarga sangat penting dalam memegang ketahanan anaknya dalam mempertahankan motivasi belajar untuk tetap mempertahankan prestasi belajar anak.

Keluarga memiliki peran yang sangat penting agar anak tetap mampu menjaga stabilitas prestasi belajarnya. Lestari (2012), menjelaskan peran orang tua dalam keluarga merupakan peran eksternal yang dapat membantu memberikan dorongan belajar pada anak

(siswa). Seyogyanya guru memiliki harapan agar siswanya tetap giat belajar, raji belajar dan tekun dalam menjalankan tugas-tugas sekolah walaupun situasi berbeda yakni menyelesaikan kegiatan persekolahan yang dipindahkan kerumah. Situasi ini tidaklah mudah dan kondisi ini

bukanlah tidak menimbulkan permasalahan yakni memudarnya semangat belajar siswa, melemahnya motivasi siswa dalam belajar, menurunnya prestasi siswa, penggunaan metode dan media pembelajaran baru yang menimbulkan konsekuensi baru pada semua lapisan masyarakat baik guru maupun orang tua sebagai garda terdepan dalam menghadapi situasi dan kondisi yang berbeda dari biasanya.

Sekolah memiliki tujuan untuk pencapaian akademik siswa dalam membudayakan sikap, keterampilan, pengetahuan dalam suatu tradisi yang ada pada suatu komunitas budaya, serta membentuk watak dan mengembangkan 
pencapaian akademik siswa (Rahmatiani. 2017). Akan tetapi dalam kondisi darurat kesehatan seperti sekarang peran orang tua dalam keluarga menjadi sangat penting menurut Arifin Aminuddin Rasyid (dalam Karmawan, Supriadi

\& Donatianus, 2012) menjelaskan kewajiban orang tua dalam keluarga ada empat yaitu:

1. Membesarkan dan merawat anak dengan cara memberi makan, minum dan juga perawatan kesehatan agar anak dapat hidup berkelanjutan dan sehat.

2. Melindungi serta menjamin kesehatan anak secara jasmani maupun rohani yang dapat mengganggu tumbuh kembang anak dari gangguan penyakit atau lingkungan yang dapat membahayakan anak.

3. Mendidikdenganilmu pengetahuandan memperkaya keterampilan guna bagi kehidupannya kelak, sehingga saat dewasa mampu bertahan diatas diri sendiri dan mampu membantu orang lain.

4. Membahagiakan anak-anaknya untuk dunia dan akhirat dengan memberinya pendidikan agama sesuai

dengan ketentuan Allah SWT, sebagai tujuan akhir hidup muslim.

Keluarga mempunyai peranan untuk mengupayakan dan mendorong perkembangan potensi anak, baik dari segi potensi afektif, kognitif, maupun psikomotorik. Potensi anak sebagai siswa mampu

berkembang berkat penguatan motivasi yang diberikan keluarga tidak hanya sebatas ucapan, tetapi juga bentuk lainnya sehingga anak (siswa) mampu membangkitkan kembali semangat dan motivasi belajarnya. Sudirman, (1990:96) mengungkapkan bahwa motivasi tinggi tercermin dari adanya ketekunan yang tidak pantang menyerah walaupun didera berbagai kesulitan yang tengah dihadapi demi menggapai sukses yang menjadi tujuan dan cita-citanya. Sardiman (dalam Karmawan dkk, 2012), mengatakan motivasi intrinsik yaitu suatu motif aktif dalam setiap diri individu yang tidak perlu dirangsang namun berfungsi sebagaimana mestinya karena setiap individu sudah memiliki dorongan untuk melakukan sesuatu. Beberapa bentuk motivasi belajar, sebagai berikut:

a. Membaca angka, sebagai 
simbol dari kegiatan belajarnya.

b. Hadiah, dapat dikatakan sebagai motivasi.

c. Saingan/kompetisi, digunakan sebagai alat pendorong motivasi belajar siswa.

d. Ego-Involvoment, menumbuhkankesadaran siswaagarmerasakan pentingnya tugas dan menerima tugas sebagai tantangan sehingga siswa mampu berusaha dan bekerja

keras dengan mempertaruhkan harga diri sebagai salah satu bentuk motivasi belajar.

e. Memberi ulangan, setiap siswa menjadi giat belajar kalau mengetahui akan ada ulangan.

f. Mengetahui hasil, dengan mengetahui hasil pekerjaan dan mendapatkan kemajuan maka mendorong siswa untuk lebih giat belajar.

g. Pujian, perlu diberikan pujian jika siswa (anak) dapat sukses dan berhasil menyelesaikan tugas dengan baik dan sempurna.

h. Hukuman, sebagai reinforcement yang negatif, tetapi dapat diberikan secara tepat dan bijak akan mampu menjadikan hukuman sebagai alat motivasi diri dalam belajar.

i. Hasrat untuk belajar, menjadi unsur kesengajaan setiap anak dalam belajar.

j. Minat, suatu motivasi akan

muncul karena adanya kesukaan yang tepat dan dapat menjadi alat motivasi yang pokok dalam setiap diri individu.

k. Tujuan, merupakan alat motivasi yang penting dalam penentu arah dalam motivasi belajar.

Peranan orang tua dalam keluarga memiliki andil yang sangat

penting dalam mendukung

keberhasilan prestasi anaknya terutama dalam hal meningkatkan motivasi belajar anak (Anurraga, 2018). Keluarga menjadi pusat utama pendidikan bagi anak. Anak yang dibesarkan dari lingkungan keluarga

yang terdidik dan memiliki pendidikan yang bagus akan mempunyai peluang besar untuk dapat tumbuh dengan baik. Peran keluarga menjadi muara dalam 
mendidik anak, mengenal kepribadian anak, kebutuhan dan perkembangan anak.

Pendidikan anak dimulai dari keluarga dan mendidik anak bermuara pada

mengenal anak dan cara

memperlakukan anak sesuai kebutuhan dan perkembangannya.

Peran keluarga dalam meningkatkan mortivasi belajar anak yaitu adanya keterlibatan dalam kegiatan belajar anak, memusatkan perhatian kondisi anak baik fisik maupun psikis, mengetahui dan memahami tingkat kemauan belajar anak, membantu mengatasi kesulitan belajar anak, dan memberikan fasilitas belajar yang memadai sesuai dengan kondisi pandemi covid-19. Pada dasarnya pada proses belajar anak pasti ada tujuan yang hendak dicapai dalam belajar, Adapun

klasifikasi hasil belajar menurut

Bloom (dalam Sunaryo, 2020) yaitu:

1. Ranah kognitif, berkenaan dengan hasil belajar pengetahuan terdiri dari enam aspek meliputi pengetahuan, pemahaman,aplikasi, analisis, sintesis, dan evaluasi.

2. Ranah afektif, berkenaan dengan sikap terdiri lima aspek meliputi penerimaan, jawaban, penilaian, organisasi, dan internalisasi.

3. Ranah psikomotorik, berkenaan dengan hasil belajar berupa ketrampilan dan kemampuan bertindak, meliputi enam aspek yaitu gerakan refleks, keterampilan gerak dasar, kemampuan perceptual, ketepatan, keterampilan kompleks, dan gerakanekspresifdan interpretatif.

Motivasi dapat tumbuh dalam diri seseorang karena adanya keinginan untuk mendapatkan apa yang menjadi tujuannya. Peran keluarga dapat mengarahkan minat belajar anak dalam penguatan 
motivasi belajar yang akan menjadi daya penggerak dalam setiap diri individu untuk dapat melakukan kegiatan pembelajaran dalam proses

meningkatkan pengetahuan, keterampilan serta pengalaman. Aruni (2018), menjelaskan bahwa motivasi menjadi faktor internal yang dapat mempengaruhi kemauan anak untuk belajar. Motivasi menjadi motor penggerak dalam kepribadian seseorang untuk dapat melakukan sesuatu sesuai dengan tujuan

tertentu. Keluarga mempunyai pengaruh yang sangat besar terhadap perkembangan kepribadian anak. Keluarga menjadi unsur yang paling utama yang dapat dijadikan tameng untuk pusat pendidikan anak dan pusat pengarahan kepribadian anak dalam pembentukan motivasi belajar.

Peran keluarga menjadi garda terdepan dalam penguatan motivasi belajar siswa, keluarga harus mampu memberikan motivasi penuh untuk anak dalam proses pembelajaran dirumah dalam menjaga prestasi akademik siswa. Melihat adanya dampak yang sangat signifikan dari pandemi covid-19 terhadap motivasi belajar siswa, maka perlunya di adakan sosialisasi peran keluarga sebagai pondasi penguatan motivasi belajar siswa di tengah pandemi covid-19 di desa jatisari kabupaten karawang.

\section{METODE}

Kegiatan pengabdian pada masyarakat dilaksanakan melalui sosialisasi peran keluarga terhadap beberapa masyarakat desa jatisari

kecamatan jatisari kabupaten

karawang. Kegiatan dilakukan berupa sosialisasi peran keluarga sebagai pondasi penguatan motivasi belajar siswa ditengah pandemi

covid -19. Pengabdian ini dilaksanakan pada bulan Agustus

2020. Kegiatan pengabdian

dilakasanakan secara online menggunakan aplikasi zoom meeting dengan metode penyampaian dalam pengabdian, yaitu:

1. Metode ceramah, menjadi salah satu metode yang sangat tepat digunakan untuk memberikan informasi kepada informan dalam layanan pengabdian. Dipilihnya metode ceramah dalam pengabdian ini berfungsi untuk memberikan 
penjelasan mengenai sosialisasi peran keluarga sebagai pondasi penguatan

motivasi belajar siswa di tengah pandemi covid-19

desa jatisari kecamatan jatisari kabupaten karawang.

2. Metode tanya jawab, metode

ini merupakan metode pemberian fasilitas untuk

melayanisebuah

kemungkinan adanya komunikasi dua arah yang terjadi antara partisipan dengan pemateri. Metode tanya jawab memiliki tujuan untuk:

1) Untuk mengetahui sejauhmana pemahaman terhadap materi dapat diterima oleh para peserta.

2) Adanya stimulus untuk merangsang peserta pengabdian agar dapat berpikir kritis.

3) Memberi kesempatan kepada para peserta untuk dapat mengajukan pertanyaanterkait dengan permasalahan yang dihadapi.

\section{HASIL PEMBAHASAN}

$$
\text { Kegiatan pengabdian pada }
$$

masyarakat dilaksanakan pada bulan

Agustus 2020. Pengabdian

masyarakat ini dilaksanakan melalui zoom meeting dengan sasaran Bapak-Ibu yang berkenan hadir pada

pertemuan zoom meeting yang

dilaksanakan di Desa Jatidari,

Kecamatan Jatisari, Kabupaten

Karawang. Pada kegiatan

pengabdian ini dilakukan secara

online memakai media zoom meeting dengan memberikan sosialisasi materi tentang peran keluarga sebagai pondasi penguatan motivasi belajar siswa di tengah pandemi Covid-19. Pada saat pemberian sosialisasi oleh pemateri pengabdian, para peserta dengan notabene masyarakat yang baru mengenal aplikasi zoom terlihat sangat antusias dalam menyimak penyampaian materi sosialisasi peranan keluarga.

Munculnya berbagai macam pertanyaan yang ditanyakan para partisipan dengan dibukanya season

tanya jawab menggambarkan antusias peserta pengabdian yang 
benar-benar memanfaatkan sesi tanya jawab guna mendapatkan pemahaman yang mereka ingin pahami secara jelas. Munculnya komunkasi yang terjadi antara peserta dan pemateri dalam kegiatan

pengabdian ini bercirikan bahwasannya pengabdian ini dapat berjalan sebagai mana mestinya dengan adanya hubungan timbal balik antara peserta dan pemateri.

Berdasarkan hasil diskusi pada sesi tanya jawab, beberapa peserta menceritakan pengalaman dan permasalahan mengenai kondisi anaknya dalam pembelajaran yang dihadapi selama ini di masa pandemi. Peranan orang tua dalam keluarga mempunyai peranan penting untuk memberikan pendidikan kepada anak-anaknya di rumah, maka anakanak (siswa) memerlukan motivasi belajar dari keluarga utamanya orang tua dalam mengapresiasikan anak agar lebih bersemangat dan bergairah sehingga akhirnya akan memiliki prestasi dalam belajar yang baik. Motivasi yang berasal dari keluarga merupakan daya penguat internal anak dalam rangka membangkitkan gairah dan semangat belajarnya, karena motivasi belajar eksternal anak diberikan oleh guru untuk mendukung prestasi akademik siswa. Motivasi yang baik adalah motivasi yang berasal dari dalam diri siswa (anak) yang bersangkutan untuk mampu mengefektifkan dirinya belajar secara aktif di rumah maupun di sekolah. Meninjau dari bentuk motivasi belajar, peran keluarga utamanya orang tua menjadi pihak yang bertanggung jawab dalam

pendidikan untuk mampu menentukan pilihan sesuai dengan keinginan, kemampuan, keadaan, dan kebutuhan dari anak/siswa tersebut. Hal ini dimaksudkan sebagai pendorong agar anak (siswa)

dapat belajar sesuai dengan kemampuan yang dimilikinya dalam

rangka meningkatkan prestasi

belajarnya. Peran keluarga merupakan hal yang penting dengan memberikan rasa kasih sayang dan perlindungan dalam pendidikan.

\section{KESIMPULAN}

Kesimpulan pengabdian

masyarakat dalam kegiatan sosialisasi peran keluarga sebagai

pondasi penguatan motivasi belajar siswa di tengah pandemi covid-19 desa Jatisari Kecamatan Jatisari Kabupaten Karawang yakni peran 
keluarga dalam meningkatkan motivasi belajar siswa (anak) sangat dibutuhkan sebab peran keluarga menjadi faktor dominan dalam pemberian dorongan keaktifan siswa dalam semangat belajar. Siswa memerlukan perhatian, nasehat orang tua sebagai pondasi semangat dalam belajar, serta memberikan fasilitas yang di butuhkan dalam belajarnya, sehingga menumbuhkan rasa ingin belajar dan terus belajar dalam diri siswa untuk menggapai impian dan cita-citanya. Peran keluarga menjadi sangat penting untuk menjaga ketahanan motivasi belajar siswa.

Pengabdian pada masyarakat ini dilaksanakan pada bulan Agustus 2020 dengan tetap mengedepankan protokol kesehatan yang ditetapkan pemerintah yaitu adanya physical distancing (menjaga jarak). Oleh

sebab itu, pengabdian pada masyarakat ini dilakukan secara online melalui aplikasi zoom dengan kegiatan sosialisasi pemberian materi mengenai keluarga sebagai pondasi penguatan motivasi belajar siswa di tengah pandemi covid-19 desa

Jatisari Kecamatan Jatisari Kabupaten Karawang.

\section{SARAN}

Kegiatan pemahaman peran keluarga terutama orang tua lebih ditingkatkan lagi terlebih untuk menghadapi pola kebiasaan baru dalam belajar karena adanya dampak dari pandemi covid-19 melalui kegiatan sosialasisai, penyuluhan ataupun pembinaan kepada orang tua maupun anggota keluarga lainnya agar peran orang tua dan anggota keluarga dengan jelas dapat mengerti dan memahami kondisi anak (siswa) ketika siswa belajar dirumah ataupun ketika siswa mendapatkan tugas sekolah yang harus dikerjakan dirumah. Pendampingan orang tua ataupun anggota keluarga lainnya menjadi sangat penting terhadap tumbuh kembangnya anak dalam semangat belajar. Dukungan fasilitas, kepedulian, serta perhatian keluarga dapat medukung prestasi akademik anak dalam meningkatkan motivasi belajar siswa (anak) ketika berada dirumah untuk mengerjakan tugas rumah ataupun dalam menghadapi keadaan sulit seperti adanya dampak

pandemi covid-19 yang merubah

pola kebiasaan baru dalam belajar. 
DAFTAR PUSTAKA

Anurraga, Hening H. (2018). Peran

Orang tua dalam

Meningkatkan Motivasi Belajar Peserta Didik Usia 6-12 Tahun (Studi pada

Program Home Visit di

Homeschooling Sekolah

Dolan Malang). Jurnal Visi Ilmu Pendidikan. Vol 7 (3).

Aruni, Saverina D. (2018). Pengaruh Peran Orang Tua Dan Sekolah Terhadap Motivasi Belajar Siswa Kelas V Sd Se-Gugus Gilangharjo Pandak Bantul Yogyakarta. Jurnal Pendidikan Guru Sekolah Dasar. Edisi 42 tahun ke-7, hal 202-211.

Karmawan, H., Supriadi., Donatianus, BSEP. (2012). Peranan Keluarga Dalam Meningkatkan Motivasi Belajar Siswa. Jurnal Tesis PMIS-UNTAN-PSS, hal $1-9$.

Lestari, $\quad$ S. (2012). Psikologi Keluarga. Jakarta: Kencana.

Rahmatiani, L. (2017). Pembentukan Karakter Siswa Melalui Program Lisa, Libra, Patujar Di Smpn 1 Cilamaya Wetan. CIVICS. Vol 2. No 1, hal 45-55.

Sudirman, SP. (1990). Psikologi Pendidikan. Bandung: PT Remaja Rasda Karya.

Sunaryo, D. (2020). Sosialisasi Buku

\begin{tabular}{|c|c|c|}
\hline Panduan Ergonor & mi "Learning Frc & $\operatorname{ari}$ \\
\hline Perhimpunan & Ergonomi & \\
\hline Indonesia & Guna & \\
\hline Meningkatkan & Motivasi & dan Pengabdian Masyarakat \\
\hline Belajar Bagi & Peserta & Vol. 3 No. 3 , hal 154-16. \\
\hline Usia Tiga & Sampai Dengan & \\
\hline Belas & Tahun & \\
\hline Kecamatan & Petir Kabupaten & \\
\hline Serang. Jurn & al Pendidikan & \\
\hline
\end{tabular}

